v. $12, n .2$

Vitória-ES, Mar.-Apr. 2015

p. 46-65 ISSN 1808-2386 DOI: http://dx.doi.org/10.15728/bbr.2015.12.2.3

\title{
The Value for the Consumer in Retail
}

\author{
Beatriz Cavalcante Chamie \\ ESPM \\ Ana Akemi Ikeda ${ }^{\Omega}$ \\ FEA/USP
}

\begin{abstract}
Shopping is not just a rational act, but also emotional, involving desire and pleasure. Therefore, retailers need to invest in actions, which create customer value, making the purchase an engaging time. The article's objective is to understand what the shoppers, the role played by a person during the shopping process, value during the purchasing experience. The research used the mean-end chains theory and the laddering technique to identify the formative value elements in a toy store. As a result, it contacted that to create value, the store should offer stimuli to assist children education, a magical and playful atmosphere, a variety that can awaken the child's desire, and foster a sense of a good purchase and the maximization of resources such as time and money. This research increases understanding, from the customer's perspective, of what is valued in a holistic shopping experience.
\end{abstract}

Keywords: Retail. Shopper. Customer value. Consumer behavior and laddering.

${ }^{\dagger}$. Master in Business Administration by São Paulo University - FEA - USP - SP - Brazil Instituition: Professor at ESPM, FIA

${ }^{\Omega}$ Professor in Marketing at FEA/USP

E-mail: bia@shoppermkt.com.br 


\section{INTRODUCTION}

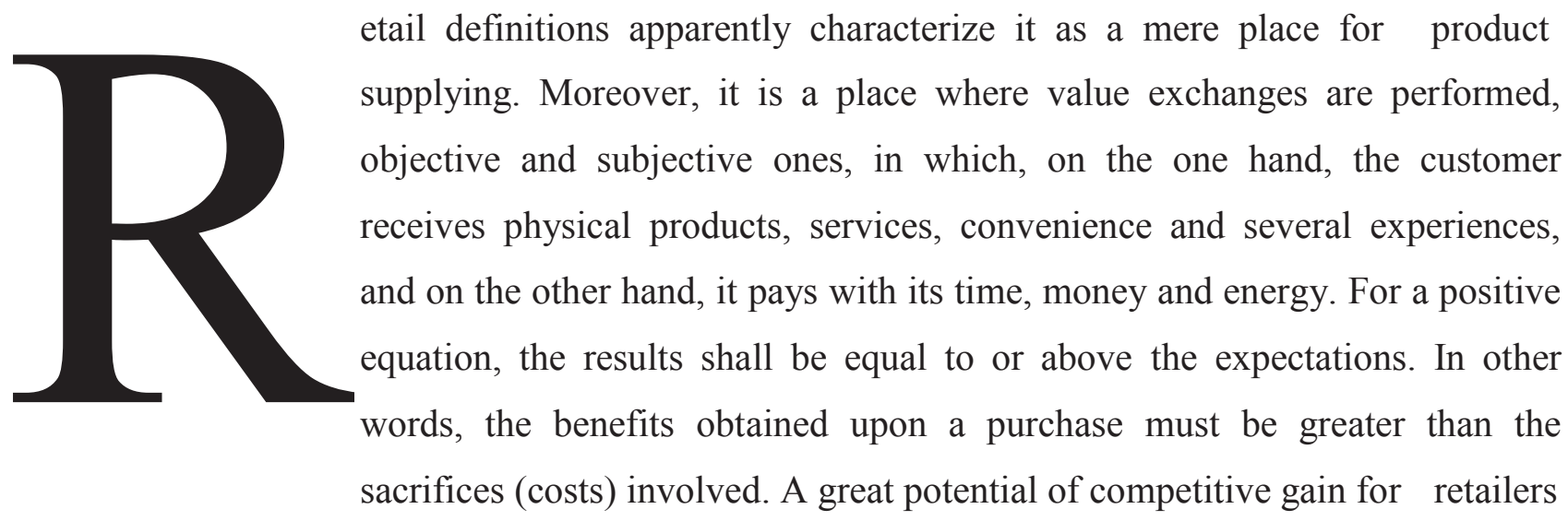

is the creation of situations and stimuli that increase the perceived benefits of the customer during the purchase act.

The understanding of the customer needs and buying behaviors is an important element for effective decision in retail (LEVY; WEITZ, 2000). According to veludo-de-oliveira and ikeda (2005), the understanding, from the customer's perspective, the meaning of value, allows enrichment, creation and enhancement of strategies in accordance with the variables of which influence it. Woodruff (1997) highlights the internal processes of an organization should have the target to give value aligned to what the customer sees as value. The comprehension of value for the customer should allow retailers to develop strategies of positioning that are more sophisticated, avoiding the creation of value built only based on the strategic stalemate of a low-price policy (COTTET et al., 2006). When retail recognizes the importance of a deep customer comprehension and it works based on that knowledge, the consumer satisfaction increases as well as the performance and success of retail (PUCCINELLI et al., 2009).

As holbrook argues (1996), the value is not just in the purchased product or in the chosen brand or in the owned object, but also in the experience derived from the purchase. It was observed an increased importance given by marketing experts to studies related to the creation of experience into the store (BABIN; ATTAWAY, 2000; BACKSTROM; JOHANSSON, 2006; BALLANTINE; JACK; PARSONS, 2010; DONAVAN et al. 1994; gentile et al, 2007; KOTLER, 1974; MASSARA; LIU; MELARA, 2010; MCGOLDRICK; PIEROS, 1998). Holbrook (1999, p. 9) explains, "experience has a central role in creating customer value." several authors use with some frequency the connections between experience and value, which are constructs with similarities in their definitions (CHOU, 2009; HOLBROOK, 2006; RAMASWAMY, 2008; SANDSTROM et al., 2008). Some authors use 
the experiential value nomenclature (WOODRUFF; WAKENSHOW, 2001), but most of them addresses the effect of experience in building value, in other words, the value created through experience, either of buying, or of consuming. A positive experience generation for the customer can provide the creation of an emotional bond between a company's brand and its customers and, in consequence, strengthen their loyalty (GENTILLE et al., 2007). According to verhoef et al. (2009), creating a superior customer experience seems to be currently one of the main objectives in the retail environment.

In the study of the customer in retail, it is necessary to understand the shopper. Shopper is the role played by a person in the purchasing process, who chooses where and what to buy, once they decide to go a physical store, online or interact with other shopping channels. The buying behavior is distinct from the consuming behavior, since their motivations, the influence of the environment, the answers and the results obtained through this process are peculiar, and influenced by the conflict of the comparison and choice.

In face of this, the goal of this research is to identify the objective and subjective factors involved in the shopping experience that create value for the shopper in the retail, which is specialized in toys. The toy retail was chosen because it is an interesting scenario for the study, since it works with themed items that meet especially the emotional and fun needs, and can thus provide an engaging and enjoyable shopping experience. It is believed that, in this sector, more than buying the toy (product), it is bought the emotion the product provides to the end user. To identify the formative elements of customer value, we used the model proposed by the means-end chains theory, where there is the mapping of attributes, consequences and personal values. The attributes and consequences (benefits) compose the factors valued by customers, which are motivated by personal values.

The importance of this work is in the understanding from the customer's perspective what it is valued in a complete shopping experience, an aspect that has been highlighted by some authors as a research opportunity. Healy et al. (2007) report that a few researches study how consumers experience the store in a holistic approach. Puccinelli et al. (2009) also point out as an important factor for future research the effect of the fun shopping experience, for desire and pleasure. On the other hand, Cottet et al. (2006) find little study on the influence of the store features about value. Verhoef et al. (2009) conclude that a superior customer experience is gaining increasing attention from retailers, however, there has been a lack of a proportional level of academic research on the subject. On the importance of children's market, Veloso (2008) states that the observation of the choice process of a toy at the point of 
sale could bring benefits to the literature. Then, observing the participation of children and their parents / relatives in the choosing of toys and the author complements this type of research could be conducted through the observation method and through interviews with the purchasing responsible, be it a parent or a relative buying a birthday present.

The study is structured with a literature review focusing the study of value from the customer's perspective and the role of shopper and your shopping experience. Then, there is the description of the work methodology, to present, then, the results and analysis of field research. Finally, there is the conclusion followed by the limitations of the study and recommendations for future research.

\section{LITERATURE REVIEW}

The following literature review aimed to present the concept of customer value, the first differentiating itself from other types of value, and then present different approaches proposed by authors. Then, it defines the roles played by the client, and thus it defines the concept of shopper and describe the factors involved in their shopping experience.

\section{a. Value under the customer perspective}

The concept of value has been studied in many areas such as marketing, economics, accounting, psychology, sociology, among others. In marketing, value is a concept that participates in various definitions of the matter as a construct that qualifies the exchange process. Ama (2007) defined marketing as an activity, set of institutions and processes to create, communicate, distribute and perform offers exchanges in order to make value for consumers, clients, partners and society as a whole. Marketing is also defined by kotler and armostrong (2007) as an administrative and social process by which individuals and organizations get what they need and want through creation and exchange of value. Thus, extracting the essence of the definitions, marketing results as an value exchange. But what exactly is value? The term appears in the literature within quite different contexts (WOODRUFF, 1997).

In marketing the concept receives influence from different areas of knowledge (RICHINS, 1994; VELUDO-DE-OLIVEIRA; IKEDA, 2005). It was in economy that began the studies of value in the context of the exchange. Richins (1994) explains that in the economical context, consumer value is represented by the price it is willing to pay and it originates from utility or satisfaction, which the good provides. The author adds the existence of several reasons to believe the economic value can not fully capture the real value of many 
objects owned by consumers, because not always what have value have economic assets too, which can be sold or exchanged. The value given to many objects, even though they may be exchanged, it may be in emotional context and not in the economic one. Kotler (1972, p. 48), in his article titled the generic concept of marketing, says that the marketing foundation is "[...] Exchange of value between two parts, which the things of value are not necessarily limited to goods, services and money; they also include other features such as time, energy and feelings. " in other words, value is traditionally originated through confrontation between benefits and costs involved, which are not always just monetary. Thereby creating value is to deliver a good balance between the benefits and costs involved in this process.

In the marketing literature, value is analyzed from the exchange context. The term may be used as having a perspective of the company or the customer and may be part of the following concepts: (i) customer equity; (ii) customer value; and (iii) customer's personal values (more linked to the field of psychology approach). These definitions, even with close nomenclatures, have completely different concepts, as can be seen in figure 1 .

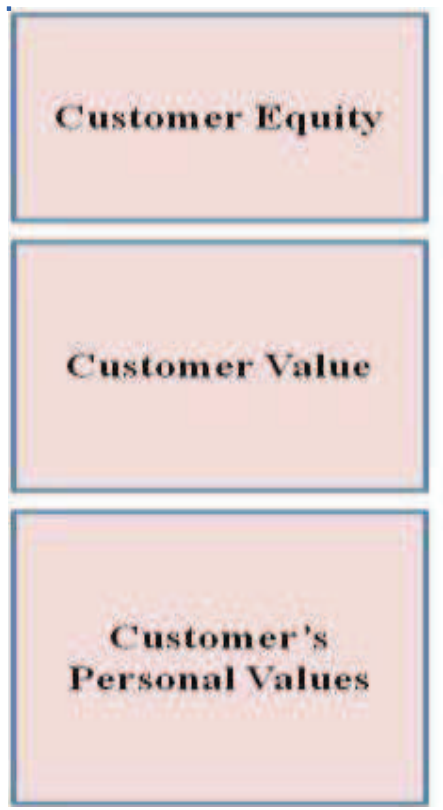

Customer equity, also know as clients' value for a company, is the total of the clients' consumption values throughou its consumption life within that company (RUST et al, 2001). Its a perspective of the company.

Customer value is a customer's overall assessment of the utility of a product based on perceptions of what is received and what is given, it is na equation between the costs and benefits involved in the exchange process (Zeithmam I, 1988). Its a customer perspective.

Personal values are the center, the core, beliefs that guide customer behavior in various situations, are long lasting and independent of the purchase situation or product use. Are motivators that drive customer in the exchange process (FLINT; WOODDRUFF, 2001), It is a customer perspective.

Figure 1 - Concepts of value.

Source: Prepared by the authors.

Among the various approaches to understand the meaning of customer value, the most frequent is the cost-benefit ratio (BYRAMJEE et al., 2010). The definitions presented in literature usually indicate an exchange relation between what is given and what is received, but not always the authors make clear a holistic view of the construction of value (ARORA; SINGER, 2006, p 93;. CHURCHILL; PETTER, 2005, page 13;. WOODRUFF, 1997, p 142;. BUTZ; GOODSTEIN, 1996, page 63;. GALE 1996: XV;. HOLBROOK, 1996, page 138;. WOODRUFF; GARDIAL 1996, p. 54; ZEITHAML, 1988 p 14). On the other hand, Shechter 
(1984, cited in ZEITHAML, 1988) proposes that value is not obtained simply by purchasing the product but by a complete shopping experience. In other words, building customer value in retail is the result of objective and subjective factors from the buying trip.

Another definition to be highlighted that is proposed by woodruff and gardial (1996), which point out that the value is created when the benefit is delivered. In other words, the products are not the only means to achieve certain goals. The client's goals are also achieved with the delivery of the consequences (benefits) resulting from the full experience lived by it, and not only by the inner characteristics of the purchased product. This relationship can be seen in figure 2.
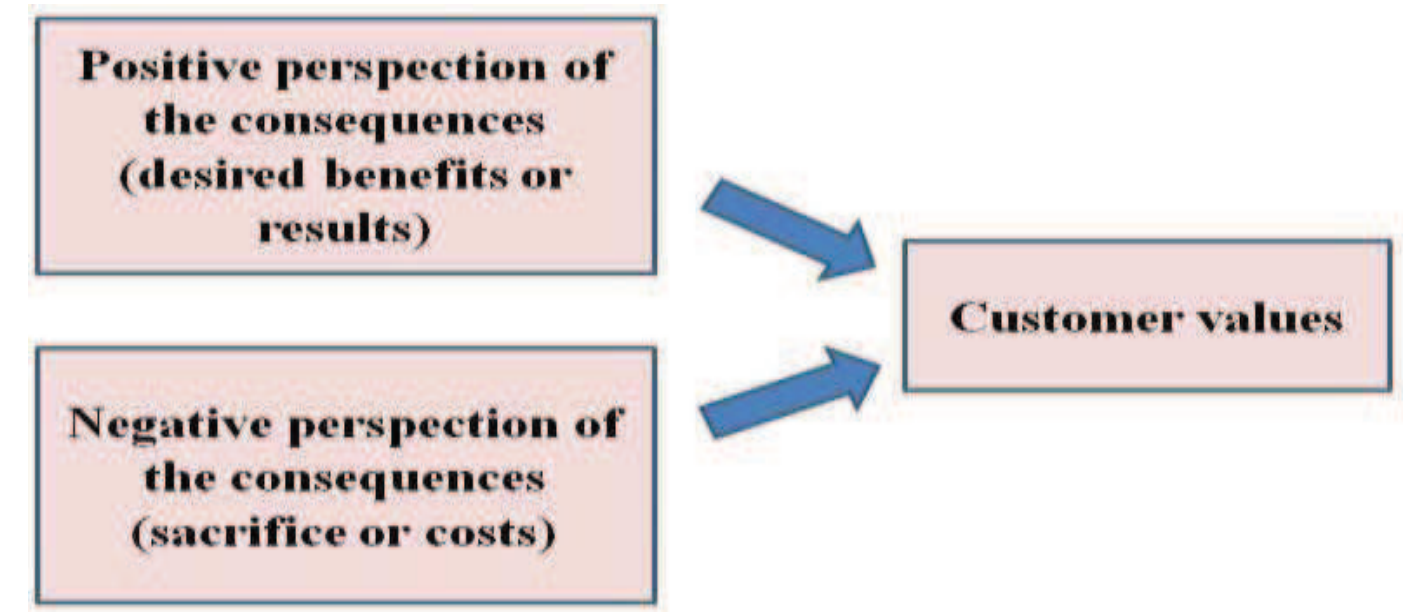

Figure 2 - Value as a result of the consequences

Source: Woodruff; Gardial 1996, p. 58.

An important distinction within the concept of customer value is the understanding of the received value and the desired value. According to flint and wooddruff (2001), the received value refers to the value the user actually experiences through interaction with a specific product (being a good or service) on the other hand, the desired value refers to what customer wants to receive from this product (good or service) and from who offers it, in many broader ways that only the desired attributes. The desired value is formed by the complete delivery of the product, attributes and consequences, positive or negative, monetary or nonmonetary, which the consumer wants it to occur. Flint and wooddruff (2001) argue the desired value changes over time, because from experience in use, clients learn to want to value new attributes with different consequences. They conclude that, from experience in all of these uses, customers learn to want or to value new attributes and vendor consequences.

Holbrook (1996, 1999) defines customer value as a realistic and interactive preferred experience. The author proposes the nature of value is an interrelationship between four dimensions: (i) interaction-relationship between the consumer and the object (product); (ii) 
relativism - comparison between objects, people and in a specific context; (iii) preference - it is related to judgment; and (iv) experience - value is not only within the purchased product, or the chosen brand or owned object, but in the experience it is derived. Moreover, sheth et al (1991a; 1991b) assert value as multifaceted, composed of a variety of forms. These different forms, according to the authors, make a difference of contribution in a situation of choice. Thus, they present five forms of customer value that will guide in the choosing of the market choice behavior. These values are identified by the choices that been made, they are: (i) functional value; (ii) the social value; (iii) emotional value; (iv) epistemic value; and (v) conditional value. In general, it can be concluded that value is something perceived by the customer of both rational and emotional ways, allowing retail to influence its outcome, but not define it objectively. Value creation during purchase can be derived from utilitarian factors, more objective and focused on traditional ways, or hedonic ones, more subjective and focused on an experiential view of consumption.

The model proposed in means-end chains theory has a way to understand the factors involved in creating customer value. That is, a model for the identification of attributes (objective characteristics), consequences (obtained benefits) and personal values (deep motivations) that assist in identifying value creating constructs, from the more objective aspects to the most subjective ones. Value is created through the delivery of benefits (consequences) that help consumers achieve their goals (FLINT, WOODRUFF, 2001). The central aspect of the means-end chains model is that the consumer chooses the actions that produce desired effects searching the minimization of the unintended consequences (GUTMAN, 1982). Gengler and Reynolds (1995) report that consumers translate the attributes of the product in the production of benefits (or consequences), and the benefits are ultimately translated into the consumer in an orientation of direction of the personal values. Within the composition of the chains, there are different levels of abstraction, and these levels form a kind of continuum, moving from the most concrete to the most abstract. These levels form the chains with: attributes (A), consequences / benefits, (C) and personal values (V). Customer value differs from personal values, but the first one is profoundly motivated by the second, thus making it to be interlinked. To think of a more tangible action plan based on what has value for the shopper, the result / benefit is one of the main points of attention. Given the depth of the approach achieved through the means-end chains theory to identify constructs trainers value, it was decided to use it as a theoretical 
framework believing that facilitates obtaining more subjective aspects beyond the scope involved at the time of purchase.

\section{b. The shopper and its shopping experience}

In the study of the customer in retail, it is necessary to understand the shopper. As shopper is a common word in english language vocabulary, there is a limited literature on its definition. The Longman dictionary (2009) defines shopper as the person who is involved in the activity of buying things in stores. On the other hand, Houaiss (1996), portuguese to english dictionary, translates shopper as the buyer, the customer. It can be noted in the portuguese language that the word closest to shopper is buyer, but buyer is a nomenclature generally characteristic of corporate activity bussiness-to-bussiness, often it chooses not to translate this term, so that its essence is maintained. In a statement, underhill translator (2009, p 3) describes: "[...] The term shopper (the one who is doing the shopping) without equivalent in portuguese, in this book means more strictly the one who is doing the retail purchase, was kept in the original."

Shopper differs from the consumer. Shopper is the person who walks in the retail environment, it is the one that makes purchases, which it may or may not be the final consumer of the product with the potential to be acquire, while the consumer is the person who has specific needs that drive the consumption of a product or service (LINDQUIST; SIRGY, 2009; ECR EUROPE, 2011). The basic difference between them is that the shopper is responsible for in-store purchase, while the consumer is the product user, and often the shopper is also the consumer. Shankar et al. (2011) describe that consumers play a different role when they are in their role of shopper, ie, deciding buying and preparing to make choices. They complement the shopper may also not be the consumer, for example, when a woman makes a purchase for her children or husband.

Some authors, in addition to separating the role of consumer and shopper also describes the role of the buyer, this is the case of Chetochine (2000). The author describes the store client can be both shopper and buyer. According to him, the shopper is the client side that is interested in knowing where and what to buy. The buyer, on the other hand, is described as the client that, once inside the store, is involved in the buying problem, product choice, sales promotions, among others, that is, it is submitted to the shopping environment. Lindquist and Sirgy (2009) extend a little more the definition of shopper, describing it as the person seeking information into the shopping environment about the products, in order to prepare itself to make or recommend a choice between options. They argue that they becomes buyer only 
when they complete the purchase transaction doing the act of payment, whether for private use, public or to another person. The authors conclude that the shopper is usually the buyer, but not always.

The distinction between client roles is stressed by Sheth et al. (2011), describing a market transaction requires at least three roles played by the customer (i) purchase (ie select) a product; (ii) pay for it; and (iii) use or consume it. Thus, defining the client can be: user / consumer (user), the buyer (buyer) or paying (payer). They describe the user or consumer as the person who actually uses the product or receive the benefits of the service; the paying is the person who finances the purchase; and the buyer is one who participates in getting products in the market. They add that each of these roles can be played by the same person and any one of them makes a person a client (customer). As there is no consensus on the subject, figure 3 contains the definitions adopted by the authors, defining the roles of: shopper, influencer, buyer and consumer.

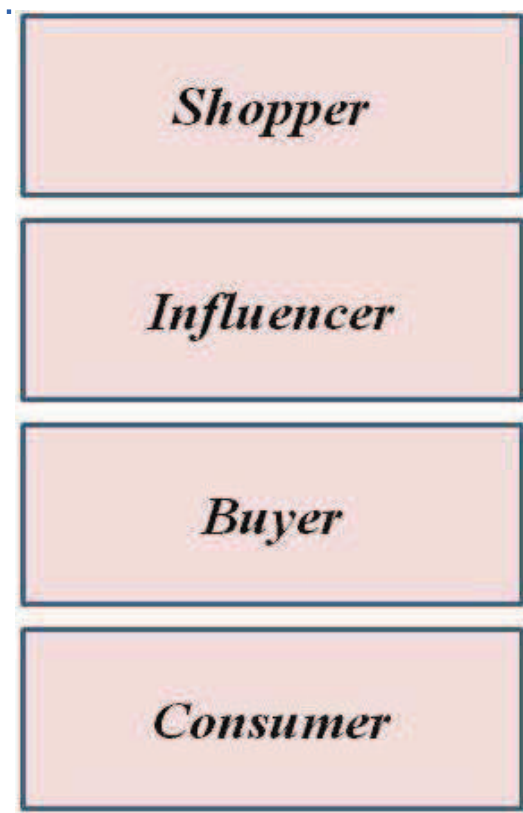

Shopper is the role played by a person in the purchasing process, who chooses where and what to buy.

The influencer is one that attempts to influence the outcome of the decision.

The buyer is the one who completes the purchase transaction and makes the payment, i.e. is one that finances the purchase.

The consumer is the one who actually makes use of the product.

Figure 3 - Roles exercised by customers

Source: Prepared by the authors.

The purchases occur when the consumer need is sufficient for time and money allocation to generate a trip to a store, or when the consumer needs attention, wants to be with its friends or in contact with people, feel the need to walk or just when you want a leisure time (TAUBER, 1972, p. 48). The same author suggests that the shopping experience can satisfy a need that is not always related to the purchase of a product. This point suggests that many retailers can benefit by defining their business as well as part of social and recreative industry, 
also offering social and recreational appeal, since compete also in time and money, with alternatives that are not retail, but can provide benefits like it.

Shoppers arrive at retail with a particular state of mind, and with a mission or purpose. Soars (2009) describes that there are three main types of missions of shoppers, as follows:

Task: the shopper when in a mission, is driven by the need and has a defined path to purchase, it may have inspirations along the way.

Complex shopping: the shopper is more likely to be influenced by the atmosphere and the communication material to aid the process. Involves more complete steps in pre-purchase thus there is more research and discussions for confirmation.

Search / recreation: in this mission, he is actively seeking will inspiration, guidelines are not the priority and there is a big opportunity in providing a seduction atmosphere

According to the author, few retailers understand the shoppers missions, as well as their mindsets involved in these processes, that is the reason they create confusing environments. It complements each shoppers group has a different set of needs and it responds differently to sensory stimuli and concludes that shoppers are more likely to spend if they feel good about themselves and in relation to shopping environment.

One becomes shopper during the purchase process, and this process can be motivated by a goal or hedonic factors as the ones described below (ARNOLD; REYNOLDS, 2003): (i) adventure: sense of exploration, pleasure, excitement and suspense by what can be found; (ii) social: creates a chance to spend time with friends and family, (iii) gratification: it is a way of relaxing or be excited, to think of other things and to forget the problems of everyday life, make it feel special in acting with a reward; (iv) inspiration: the window generates inspiration, updates on fashion, trends and technology. It is like a hobby; (v) to others: buy for others is more pleasurable, to give a gift and to find something really special that a person likes is like a huge satisfaction and; (vi) opportunity: it is like a game in search of deals and opportunities where the goal is to use the money the best way possible.

Shoppers consciously have a rational reason to make the purchase, but the subconscious emotions play an important role (SOARS, 2009). Shoppers motivated by hedonic factors are called by some authors as recreational shoppers (KALTCHEVA; WEITZ, 2006). Bellenger and korgaonkar (1980) conducted a study that shows the importance of shoppers who seek a recreational nature during their purchasing act, as opposed to shoppers who buy for 
convenience or economic factors (also called task-oriented). They are those who dislike or are indifferent to the act of buying and are looking primarily for savings of money or time in retail, since the act of purchase is not a pleasant use of their time. Recreational shoppers take pleasure in the act of purchase and want more than just saving time or money. According to the authors, recreational shoppers are more engaged in unplanned purchases, spend more time shopping, are more likely to keep walking through the shops after making the purchase, and are more interested in finding information. In their study, a panel of 224 respondents, recreational shoppers represented $69 \%$ of cases. They are usually women, who use of the act of purchase also as a social interaction activity and they seek for a pleasant shopping atmosphere.

Soars (2003) states that the shoppers who feel smart, inspired and positive are the ones who spend more time in the store and buy more, also driven by the psychology of time perception. He complements the shopping experience and the time savings are as important for a shopper as money is, because when a shopper enjoys a buying trip, it buys what he planned more quickly than anticipated, finding the products easily, so they are positive, and therefore more likely to a greater spending in the retail, as if there is a symbiosis between what they are doing as shoppers and what the environment is doing for him. The challenge is to create an environment that fosters a unique relationship with the store. Retailers must create a focused mind in problem solutions based on complete shopper's needs and not only categories of solutions (SHANKAR, et al., 2011).

Due to the increasing importance of the role of the person in the act of purchase, practitioners and scholars rise to a new concept, which is called shopper marketing. Shopper marketing relates to the use of marketing tools and knowledge of the habits and attitudes of shoppers to create value of trade between the parties involved. Shopper marketing refers to the planning and implementation of all marketing activities that influence shopper, throughout their buying journey, in which the goal is to achieve a win-win a shopper solution, to supplier and to retail (SHANKAR et al., 2011). The authors add that the concept has strategic and tactical differences compared to traditional marketing, since the traditional focuses on consumers and their consumption patterns, while the shopper marketing targets the customer upon purchase.

\section{STUDY METHODOLOGY}

The research was qualitative, exploratory and descriptive with a mixed approach, with the laddering technique using the means-end chains theory. The technique enabled the 
identification of the component elements of the dimensions of value for shoppers and their interrelations. Laddering is a technique used to understand behavior, which has been especially used in marketing to explore personal opinions, actions and beliefs and it is widely recommended in research on value, by means-end theory (VELUDO-DE-OLIVEIRA et al., 2006). Reynolds and gutman (1988) reported that the interviewed should feel like it is in a self-discovery trip, which objective is to revisit the common experiences and examine its premises and wishes to conduct seemingly simple choices.

According to veloso and hildebrand (2013), 9 years old children already have some knowledge of the purchase and consumption acts, but have yet to develop a broader understanding of the same. Therefore, the field research was carried out with 15 shoppers, mothers of children between 2 and 8 years residents of the greater são paulo, in the groups of economic classification b1, a2 or a1 (ABEP, 2009) who visited at least three times a toy retailing in the six months preceding the interview.

\section{RESULTS AND ANALYSIS OF FIELD RESEARCH}

The interviews resulted in 155 ladders, with an average of 10 ladders per interviewed. After obtaining these formative elements of value as the total outcome of the interview, the present study followed the analysis and interpretation technique of the data proposed in laddering, consisted of: (i) construction of the implications matrix summarizing the direct and indirect relations between the different elements; (ii) construction of the hierarchical value map at which it can be seen in a very visual way the priority connections between the forming elements of shopper value to, finally, (iii) identification of the dominant perceptions guidelines determinations, from a calculation to obtain the main chains due to the field research. Through the most significant chains, it was possible to obtain the value meaning representations for the shopper in the toy shopping experience.

The main representations of value to the shopper in the toy shopping experience can be seen in figure 4, which presents six major themes. The representations were: i) the toy store is a mean to obtain stimuli that helps in children's education; (ii) the magical and playful stimuli evoke memories and fantasies; (iii) time and money are important resources at the time of purchase; (iv) the sought toy is the one that awakens the child's desire; (v) the offered variety is important to support choice; and (vi) the feeling of doing a good buy is a desired factor. Most depictions show subtopics, which are spin-offs from the main representation in order to give a more specific meaning to the set of elements that compose it. 
1. The toy store is a means to obtain stimuli that help in the formation of children.

a) The quality and benefits of the assortment offered as a means to obtain stimuli.

b) The importance of the presence of toys interpreted as useful, as well as educational toys, books, construction toys and games in the store inventory.

c) The information and the staff shop as a means to facilitate the search for stimuli.

2. The magical and playful stimuli evoke memories and fantasies.

a) The fantasy world.

b) When I was a kid, it was like that...

3. Time and money are important resources at the time of purchase.

a) Expensive gifts only on special occasions.

b) The time is worth a lot.

4. The sought toy is one that awakens the child's desire.

a) Something to develop the child in a fun way.

b) Freedom and imagination to awaken the child's desire.

5. The variety offered is important to support the choice.

6. The feeling of doing a good buy is a desired factor.

a) Costs and benefits involved in the purchase.

b) The importance of effective communication in the store.

Figure 4 - Main Representations Of Value To The Shopper In The Toy Shopping Experience Source: Representation Proposed By The Authors.

The toy store is, to the interviewees, an entertainment, imagination and fun venue. When asked about the meaning of the store, many of them preferred the description of the toy's meaning, because, after all, the toy store is a playhouse. Toys have a very special role in people's lives and, therefore, the toy store is seen with a playful and special place, as described by the shopper 4: "Buying a toy ... reminds me magic, dream, think it's buying fun". The shopper 13 adds: "The Toy Store is a place where fun is found, for both adults and children."

According to reports of the mothers interviewed (shoppers), once they enter the store, they consider the buying process fun for being involved with the environment. Many said going to the mall is necessarily obligated to go to toy stores, and those in a hurry avoid passing in the hallway, but many children insist on visiting in the very moment of the entrance into the mall. For some mothers, to enter the toy store means buying, but for others this association does not always occur, because the store is also seen as an entertainment venue for children. Therefore, the role of toy shop for mothers is marked by extremes. On the one hand, the toy store is seen as an entertainment venue where mothers choose to take their children to spend a pleasant time, not tying the trip to the store to the need of products purchase, characterized as a essentially hedonic shopping trip. On the other hand, some mothers have a big fear in taking children to toy stores and so prefer going alone, because they believe they will face embarrassing situations with a child who asks everything. There is also a significant difference in shopping behavior when shoppers are accompanied or 
unaccompanied by their children. On this, the shopper 14 describes: "if i'm alone, it is a job, a must (however i have pleasure), but if i'm with him (son), it is great fun." but there are those who disagree and say exactly the opposite. It was noted that, in general, children are the great motivators of purchase and, often, those who choose leave mothers with a final approval role.

The negative aspects mentioned in interviews about the store usually revolved around: qualification and amount of the team of attendants, assortment, lack of space to move around, mess in the store, high accumulation of people on special dates such as christmas, but mainly lack of communication in product price.

In general, the toy store is seen as a place of entertainment, fun and imagination so the main associations made are positive. The physical stores are the preferred for shopping toys, and shoppers seek online stores only if they want something specific and hard to find in a physical store, because they like to touch and see the physical product before purchasing.

\section{CONCLUSIONS}

The mapping of value formative elements made possible to see the positive exchange relation in the cost-benefit equation under the perspective of the person responsible for purchasing, i.e. The shopper. In the present study case, the shopper is the mother who has often different goals of the consumer, which in this case is predominantly the child. The consumer has a large influence on the time of purchase, whether present or not. The great shopper expectations is the satisfaction of the child, awakening her desire. Moreover, the search for something that aids in the formation and development of consumers (children) proved to be a priority in the selection process. That is, consumer interest (child) occurring together with the interest of the shopper, which in this case is the mother concerned about the child's educational process.

Through exploratory research, we can observe both the importance of recreation shopping mission as those powered by task within the researched retail profile. The research revealed that shoppers often have little clarity about what will be purchased, beginning a process of search and inspiration and want to be seduced in store for magic stimuli, atmosphere referring to fantasy and remembering childhood. That many shoppers also seek the store as a kind of recreation for their children, a form of entertainment, which does not necessarily result in a buying process. Thus, we see a large occurrence of shoppers recreational (KALTCHEVA; WEITZ, 2006; BELLENGER; KORGAONKAR, 1980) who feel pleasure in the buying act and who want more than just saving time and money because they engage themselves in a not planned shopping and are interested in 
finding information. On the other hand, there are those who avoid taking their children to the shops, for even if they become involved with the environment, they seek a more practical aspect, aimed to solve a task, usually gift purchasing. This task is motivated by a search for confidence in the selection process, as well as to save time and money resources.

Soars (2009) states that the shoppers, often have a rational reason to make their purchases, but the subconscious emotions play an important role, which was confirmed in this study. The importance of hedonic experience was evident mainly by the appreciation of magical and playful stimuli in the shopping environment, but it was also made present in other representations that value imagination and the playfulness in store. That is, the playful retail, or toy retail, can have an even larger space within the development of experiential strategies, as well as other retail profiles. Based on the results of the study, it is concluded that in order to create value for the customer, it is essential to have a positive equation between the delivery of benefits and costs involved. The main benefits and costs are shown in figure 5 . Retail should seek maximization of all the benefits and minimization of costs involved in the buying process.

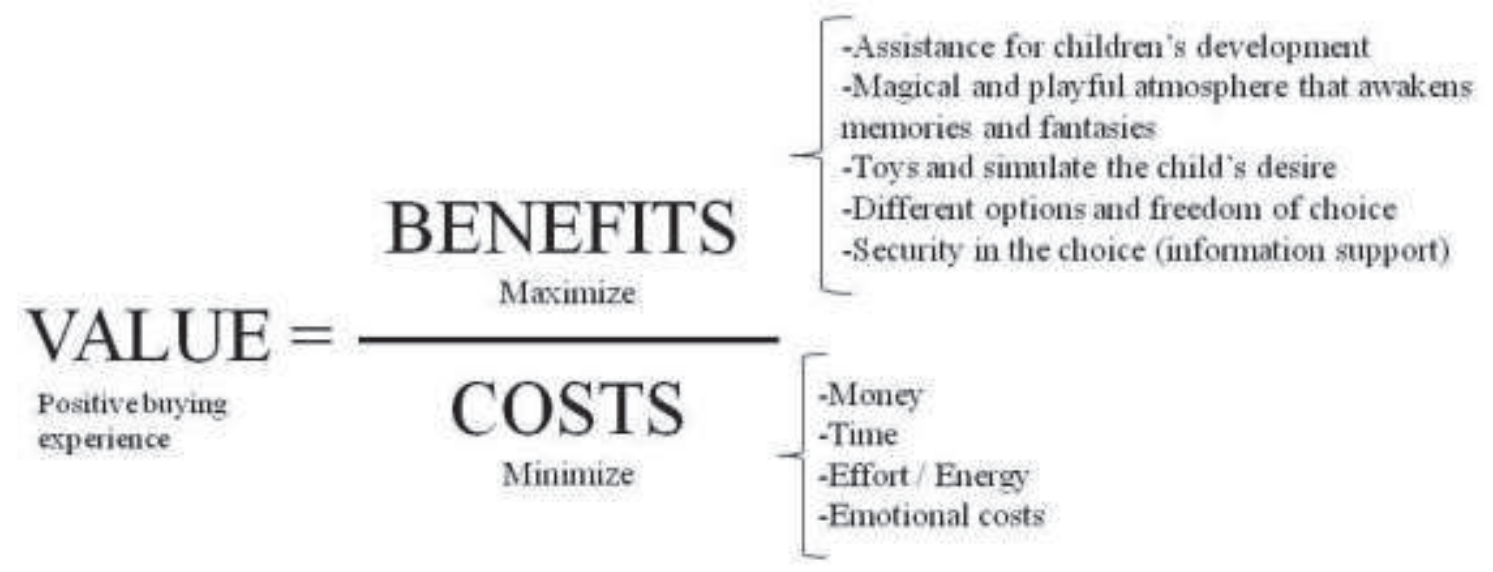

Figure 5 - value representation in the toy shopping experience Source: Representation Proposed By The Authors.

Stimulated environments to an experience where hedonic values are sought indicate having less dependence on low prices and promotions, as experience in purchase is composed by the delivery of the product, which is not formed only by the good (toy), but also for the service provided by retail. The results suggest the experiential value created by the stores influences the time of purchase and the pleasure the shopper feels during this process. Woodruff (1997) states that once it is understood what the target customer values, the retail can prioritize the various value dimensions identified, and reflect about how they act 
toward those elements. This should go through a reflection on how retail do to listen to their customers for real, or only listen when there are complaints.

Backstrom and Johansson (2006) pointed out that retailers are increasingly using advanced techniques to create engaging experiences for their customers in the stores, but the representation obtained by consumers shows that their experiences at the store, largely consist of traditional values, such as personal behavior, a satisfying selection of products and layout that facilitates movement within the store. the present study supports this point, since one of the greatest identified opportunities concerns worked assortment, communication / information in the store and sales staff, basic aspects of store management that are still being criticized by the target audience goer.

It is considered that this study provides a new perspective on how to get the value representations within a given retail profile because the methodology used in retail, although exploratory, proved to be very useful to obtain a holistic view on the value perception in shopping experience. the term customer value often is used in a very general way, and the understanding of the elements that compose it brings a wealth tangibilization in this concept so important to the area marketing.

\section{STUDY LIMITATIONS AND RECOMMENDATIONS FOR FUTURE RESEARCH}

Because it is a qualitative research, the main limitation is a result of non-representation and consequently impossibility of the results generalization because of the public profile chosen, region and retail type. The second limitation is due to the restricted panel of interviewed people, due to the fact the laddering technique includes lengthy interviews, increasing the coverage difficulty. On the other hand, the large amount of detail obtained by the method proved to be efficient for the purpose of this research. Some issues from this research, which can be verified in future studies are: How retailers can develop in store aspects valued by their customers? What retailers are doing to deliver shopping experiences of greater value for customers? What are the key attributes in a hedonic purchase versus utilitarian? Do the customer value in retail depends on the segment in which it operates? What are the values that lead to impulse buying? The customer value in retail is still a relatively unexplored subject; it has a big unexplored space for additional contributions, leaving more complete the focused marketing literature in the sector. 


\section{REFERENCES}

ABEP - Associação Brasileira de empresas de pesquisa. Critério de Classificação Econômica Brasil. 2009. Disponível em:

$<$ http://www.abep.org/novo/Content.aspx?ContentID=301>. Acesso em: 22 jun. 2011.

AMA - American Marketing Association. Dictionary of marketing terms. Acessado em 07 de abril, 2011, em

http://www.marketingpower.com/Community/ARC/Pages/Additional/Definition/default.aspx

ARNOLD, M.J.; REYNOLDS, K. E.. Hedonic Shopping motivation. Journal of Retailing, v. 79, n. 2, p. 77-95, 2003.

ARORA, R.; SINGER, J.. Customer satisfaction and value as drivers of business success for fine dining restaurants. Services Marketing Quartely, v. 28, n. 1, p. 89-102, 2006.

BABIN, B. J.; ATTAWAY, J. S.. Atmospheric affect as a tool for creating value and gaining, share of customer. Journal of Business Research, v. 49, n. 2, p. 91-99, 2000.

BACKSTROM, K.; JOHANSSON, U.. Creating and consuming experiences in retail store environments: comparing retailer and consumer perspectives. Journal of Retailing and Consumer Services, v. 13, n. 6, p. 417-430, 2006.

BALLANTINE, P. W.; JACK, R.; PARSONS, A. G. Atmospheric cues and their effect on the hedonic retail experience. International Journal of Retail \& Distribution Management, v. 38 , n. 8, p. 641-653, 2010.

BELLENGER, D.N.; KORGAONKAR, P.K. Profiling the recreational shopper. Journal of Retailing, v. 56, n. 3, p. 77-92, fall, 1980.

BUTZ, H.JR.; GOODSTEIN, L.D. Measuring Customer Value: Gaining the Strategic Advantage. Organizational Dynamics, v. 24, n. 3, p. 63-77, 1996

BYRAMJEE, F.; BHAGAT, P.; KLEIN, A. The moderation rof of relationship quality in determining total value orientation. Global Journal of Business Research, v. 4, n. 2, p. 4962,2010 .

CHETOCHINE, G. Marketing estratégico da distribuição. São Paulo: Makron Books, 2000 .

CHOU, H.J. The effect of experiential and relationship marketing on customer value: A case study of international American casual dining chains in Taiwan. Social Behavior and Personality, v. 37, n. 7, p. 993-1008, 2009.

CHURCHILL, G.A.; PETER, J. P. Marketing: criando valor para os clientes. São Paulo: Saraiva, 2005.

COTTET, P., LICHTLE, M. C.; PLICHON, V. L. The role of value in services: a study in a retail environment. Journal of Consumer Marketing, v. 23, n. 4, p. 219-227, 2006.

DONAVAN, R. J. et al. Store atmosphere and purchasing behavior. Journal of Retailing, v. 70, n. 3, p. 283-294, 1994. 
ECR EUROPE. The consumer and shopper journey framework. Europa: ECR, 2001.

FLINT, D.J.; WOODRUFF, R.B.; GARDIAL, S.F. Customer value change in industrial marketing relationship: a call for new strategies and research. Industrial Marketing Management, v. 26, n. 2, p. 163-175, 1997.

FLINT, D.J.; WOODRUFF, R.B. The Initiators of Changes in Customers' Desired ValueResults from a Theory Building Study. Industrial Marketing Management, v. 30, n. 4, p. 321-337, 2001.

GALE, B.T. Gerenciando o valor do cliente: criando qualidade e serviços que os clientes podem ver. São Paulo: Pioneira, 1996

GENGLER, C.E.; REYNOLDS, T.J. Consumer understanding and advertising strategy: analysis and strategic translation of laddering data. Journal of Advertising Research, v. 35, n. 4, p. 19-33, jul.-aug., 1995.

GENTILE, C.; SPILLER, N.; NOCI, G. How to Sustain the Customer Experience: An Overview of Experience Components that Co-create Value with the Customer. European Management Journal, v. 25, n. 5, p. 395-410, 2007.

GUTMAN, J. A Means-End Chain Model Based on Consumer Categorization Processes. The Journal of Marketing, v. 46, n. 2, p. 60-72, spring, 1982.

HEALY, M. J. et al. Understanding retail experiences: the case for ethnography. International Journal of Marketing Research, v. 49, n. 6, p. 751-778, 2007.

HOLBROOK, M. B. Consumer value: a framework for analysis and research. Advances in Consumer Research, v. 23, n. 1, p. 138-142, 1996.

HOLBROOK, M.B.. Consumer Value: a framework for analysis and research. New York: Routledge Interpretive Market Research Series, 1999.

Consumption experience, customer value, and subjective personal introspection: An illustrative photographic essay. Journal of Business Research, v. 59, n. 2, p. 714-725, 2006.

HOUAISS, A.. Novo dicionário Folha Webster's: inglês/ português, português/ inglês. São Paulo: Folha da Manhã, 1996.

KALTCHEVA, V. D.; WEITZ, B. A. When should a retail create and exciting store environment? Journal of Marketing. v. 70, n. 1, p. 107-118, jan., 2006.

KOTLER, P.; AMSTRONG, G. Princípios de Marketing: 12. ed. São Paulo: Prentice Hall: 2007.

KOTLER, P. A generic concept of Marketing. Journal of Marketing, Chicago, v. 36, n. 2, p. 46-54, apr., 1972.

Atmospherics as a marketing tool. Journal of Retailing, Oxford, v. 49, n. 4, p. 4864, winter, 1973-1974.

LEVY, M.; WEITZ, B.A. Administração de varejo. São Paulo: Atlas, 2000. 
LINDQUIST, J.D.; SIRG, M.J.. Shopper, Buyer, and consumer behavior: Theory, Marketing application and Public Policy Implication. 4th. ed. Ohio: Cengage Learning, 2009.

LONGMAN Dictionary of Contemporary English. 5th ed. New York: Pearson Longman, 2009.

MASSARA, F.; LIU, S. S.; MELARA, R. D. Adapting to a retail environment: modeling consumer- environment interaction. Journal of Business Research, v. 63, n. 7, p. 673-681, 2010 .

MCGOLDRICK, P. J.; PIEROS, C. P. Atmospherics, pleasure and arousal: the influence of response moderators. Journal of Marketing Management, v. 14, n. 1, p. 173-197, 1998.

PUCCINELLI, N. M. et al. Customer experience management in retailing: understanding the buying process. Journal of Retailing, v. 85, n. 1, p. 15-30, mar., 2009.

RAMASWAMY, V. Co-creating value through customers' experiences: the Nike case. Strategy \& Leadership, v. 36, n. 5, p. 9-14, 2008.

REYNOLDS, T.J.; GUTMAN, J. Laddering theory, method, analysis, and interpretation. Journal of Advertising Research, v. 28, n. 1, p. 11-31, feb.-mar., 1988.

RICHINS, M. L. Valuing things: the public and private meaning of possessions. Journal of Consumer Research, Chicago, v. 21, n. 32, p. 504-521, dec., 1994.

SANDSTROM, S. et al. Value in use through service experience. Managing Service Quality, v. 18, n. 2, p. 112-126, 2008.

SCHECHTER, L. A Normative Conception of Value. Progressive Grocer, Executive Report, p. 12-14, 1984 apud ZEITHAML, V.A. Consumer perception of price, quality, and value: a means-end model and synthesis of evidence. Journal of Marketing, v. 52, n. 3, p. 2-22, jul., 1988.

SHANKAR, V. et al. Innovations in Shopper Marketing: Current Insights and Future Research Issues. Journal of Retailing, v. 87, n. 1, p. 29-42, 2011.

SHETH, J.N.; MITTAL, B.; NEWMAN, B.I. Comportamento do Cliente: indo além do comportamento do consumidor. São Paulo: Atlas, 2011.

SHETH, J.N.; NEWMAN, B.I.; GROSS, B.L.. Consumption values and market choices: theory and applications. Ohio: South-Western Publishing CO, 1991a.

$\therefore$;_ Why we buy what we buy: a theory of consumption values.

Journal of Business Research, v. 22, n. 2, p. 159-170, 1991 b.

SOARS, B. Driving sales through shoppers'sense of sound, sight, smell and touch.

International Journal of Retail \& Distribution Management, v. 37, n. 3, p. 286-298, 2009.

What every retailer shoud know about the way into the shopper's head.

International Journal of Retail \& distribution Management, v. 31, n. 12, p. 628-637, 2003. 
TAUBER, M. E. Why Do People Shop? The Journal of Marketing, v.36, n.4, p. 46-49, 1972.

UNDERHILL, P. Vamos ás compras: A ciência do consumo nos mercados globais. Rio de Janeiro: Elvesier, 2009.

VELOSO, A.R.; HILDEBRAND, D.F.N.. Representação visual do ato da campa para a criança de famílias de alta renda. BBR- Brazilian Business Review, v. 10, n. 3, p1-33, jul-set 2013.

VELOSO, A. R.. Estratégias de segmentação e posicionamento direcionadas para o mercado infantil. São Paulo: 2008. Tese (doutorado)- Programa de Pós-Graduação em Administração de Empresas, Faculdade de Economia, Administração e Contabilidade da Universidade de São Paulo, 2008.

VELUDO-DE-OLIVEIRA, T. M.; IKEDA, A. O conceito de valor para o cliente: definições e implicações gerenciais em marketing. Read, ed. 44, v. 11, n. 2, p. 1-8, mar.-abr. 2005.

VELUDO-DE-OLIVEIRA, T. M.M.; IKEDA, A.; CAMPOMAR, M.C. Laddering in the practice of marketing research: barriers and solutions. Qualitative Market Research: An International Journal. v. 9, n. 3, p. 297-306, 2006.

VERHOEF, C. P. et al. Customer experience creation: determinants, dinamics and management strategies. Journal of Retailing, v. 85, n. 1, p. 31-41, mar., 2009.

WOODRUFF, H.B.; WAKENSHAW, S. Revisiting experiential values of shopping: consumers' self and identity. Marketing Intelligence e Planning, v. 29, n. 1, p. 69-85, 2011.

WOODRUFF, R. B.; GARDIAL, S. F. Know Your Customer: new Approaches to Customer Value and Satisfaction. Cambridge, MA: Blackwell Publishers, 1996.

WOODRUFF, R. B. Customer value: the next source of competitive advantage. Journal of Academy of Marketing Science, Coral Gables, v. 25, n. 2, p. 139-153, spring, 1997.

ZEITHAML, V. A. Consumer perceptions of price, quality and value: a means-end model and synthesis of evidence. Journal of Marketing, v. 52, n. 3, p. 2-22, jul., 1988. 